\title{
Agroforestry Land Use Systems for Climate Change Adaptation and Mitigation in Ethiopia: A Review
}

\author{
Abiot Molla Agemas \\ Department of Natural Resource Management, Debremarkos University, Debremarkos, ETHIOPIA
}

\begin{abstract}
Deforestation and forest degradation are major contributors to recent increases in atmospheric greenhouse gas concentrations and changes to the world's hydrological cycle. For instance most of the European countries, the industrial process emissions are typically $1-2 \%$ of total emissions in the world. In Ethiopia, the current contribution is very low as compare to a global scale, but will more than double from $150 \mathrm{MtCO}_{2} \mathrm{e}$ to $400 \mathrm{Mt}$ $\mathrm{CO}_{2} \mathrm{e}$ in 2030. Realizing the threat of global warming, reducing Emissions from Deforestation and Degradation (REDD+) both the Kyoto Protocol in 1992 and Paris climate change agreement in 2012 were built. To upon these commitments Ethiopia has adopted a new, sustainable development model by initiating the ClimateResilient Green Economy (CRGE) for achieving the following four pillars: i) Improving crop and livestock production while reducing emissions; ii) Protecting and reestablishing forests; iii) Expanding electricity generation from renewable sources v) Use of modern and energy-efficient technologies. Among many climate smart Agriculture practice in Ethiopia, Agroforestry is the one which is inclusive others agricultural practicing. The aims of this paper were to reviews the possible opportunities to raise the potential environmental role of agroforestry in supporting the climate smart agriculture in Ethiopia.Studies on indigenous agroforestry systems in southeastern Ethiopia indicated that, the average total biomass carbon stock were, Coffee accounted for $11 \%$ and Enset $9 \%$ of total biomass $C$ on average of which trees accounting for $39-93 \%$ of the total biomass carbon stock. On the other hands, SOC stocks $(0-60 \mathrm{~cm})$ were $109-253 \mathrm{Mg} \mathrm{ha}^{-1}$ in the indigenous agroforestry systems. Various agroforestry systems practice in different parts of Ethiopia has also contributed to biodiversity conservation. One of the oldest indigenous agroforestry systems that were practiced in Hararghe highlands of eastern Ethiopia is the retaining of scattered apple-ring Acacia (Faidherbia albida (Delile).Therefore, an Agroforestry practice provides both provisioning and regulating services and there by contributing to the mitigation of global climate changes.
\end{abstract}

Keywords, Agroforestry, climate change, climate smart

DOI: $10.7176 / \mathrm{JBAH} / 9-8-02$

Publication date: April $30^{\text {th }} 2019$

\section{Introductions}

The major challenges of global environment are accumulation of heat trapping greenhouse gasses, which raise the global temperature regime, stratospheric ozone depletion, pollution of air, deforestation and degradation of ecosystems and loss of biodiversity (IPCC, 2007). Population growth, industrialization and urbanization are cited as the driving forces of environmental changes. Deforestation and forest degradation are now widely acknowledged by the scientific community as major contributors to recent increases in atmospheric greenhouse gas (GHG) concentrations and changes to the world's hydrological cycle (Hansen et al., 2013). For example, in the City of Paris internal automobile trips generate emission of $3,670 \mathrm{kt} \mathrm{CO}_{2} \mathrm{e}$, while trips with origins or destinations outside of the City contribute 2,862 $\mathrm{kt} \mathrm{CO}_{2} \mathrm{e}$ (Mairie de Paris, 2009). For most of the European countries, the industrial process emissions are typically $1-2 \%$ of total emissions in the world (Carney et al, 2009). Ethiopia's contribution to GHG emissions is very low as compare to a global scale. However, if current practices prevail, GHG emissions in Ethiopia will more than double from $150 \mathrm{MtCO}_{2} \mathrm{e}$ to $400 \mathrm{Mt} \mathrm{CO}_{2} \mathrm{e}$ in 2030(Ethiopian CRGE, 2011). Out of the $150 \mathrm{Mt} \mathrm{CO}_{2}$, more than $85 \%$ of GHG emissions came from the agricultural and forestry sectors followed by power, transport, industry and buildings, which contributed 3\% each (Ethiopian CRGE, 2011). If the current rate of land use conversion continues, GHG emissions from Ethiopia will increase from 150 million Mg CO2e in 2010 to 400 million Mg CO2e in 2030 (Bishaw et al. 2013).

Realizing the threat of global warming, United Nations established the IPCC and created the Kyoto Protocol by United Nations Framework Convention on Climate Change (UNFCCC) as the first international agreement on mitigating GHGs, in 1992. The goal of this protocol is to reduce the GHGs of committed countries by at least 5\% compared to the 1990 level, Reducing Emissions from Deforestation and Degradation (REDD+) by the period 2008-2012 (Van Kooten, 2000). However, the agreement has not been done in the year of 2012. The recent agreement in Paris on December 2015 was built on the foundations of the UNFCCC on Climate Change. The Agreement requires all countries developed and developing to make significant commitments to address climate change. Countries responsible for 97 percent of global emissions have already pledged their Nationally Determined Contributions (NDCs) for how they will address climate change. Countries will revisit their current pledges by 2020 and, ideally, strengthen their emissions reduction targets for 2030. To upon these 
commitments Ethiopia has adopted a new, sustainable development model by initiating the Climate-Resilient Green Economy (CRGE) for achieving the following four pillars (CRGE, 2011):

1) Improving crop and livestock production practices for higher food security and farmer income while reducing emissions; 2) Protecting and reestablishing forests for their economic and ecosystem services, including as carbon stocks; 3) Expanding electricity generation from renewable sources of energy for domestic and regional markets; 4) Use of modern and energy-efficient technologies in transport, industrial sectors, and buildings. Among many climate smart Agriculture practice in Ethiopia, Agroforestry is the one which is inclusive others agricultural practicing.

Agroforestry is defined as "an ecologically based natural resource management system that integrates trees with crop and/or animal on farms with aim of diversifying and sustaining income and production while maintaining ecosystem services" (ICRAF 2000). Agroforestry provides a number of ecosystem services. It includes provisioning Services such as diversification of household income, regulating services such as soil conservation, watershed protection, sinks for carbon and there by contributing to the mitigation of global climate changes (Jose and Bardhan, 2012).

This paper reviews the possible opportunities to raise the potential Environmental role of agroforestry in supporting the climate smart agriculture in Ethiopia. Moreover, to identifies the opportunities and challenge of practicing agroforestry in Ethiopia.

\section{Climate smart Agroforestry practice In Ethiopia}

\subsection{Description of the major types of Agroforestry practice and systems in Ethiopia}

Agroforestry practice in Ethiopia is not a new concept rather an age-old practice whereby farmers maintain trees on croplands. Integration of tree/shrub species into the agricultural crop is emerged together with agriculture (Hailu \& Asfaw, 2011). The growing of fruit crops in isolated gardens started during the early periods of Christianity in Ethiopia (SLUF, 2006). The same report indicated that cultivation of both domesticated and wild fruits were concentrated in monasteries and churches as sources of food for nuns, monks, hermits and warriors. The total area that is covered by an agroforestry system in Ethiopia is not well-documented (Brown et al., 2012). According Brown et al., 2012, some estimates based on satellite imagery it was around 2.32 million ha by excluding scattered trees on crop and grazing lands. Though type of agroforestry practice not yet well documented in Ethiopia, Hoekstra et al. (1990) by considering altitude, topography, and intensity of land use systems identified eight AFPs like alley cropping, trees in homegardens, fodder tree planting, trees as living fences, farm boundary and road side planting, trees on contour bunds, and gully planting as age-old AFPs in Ethiopia. Other study identified nine types of AFPs in various parts of Ethiopia providing diverse ecological and socioeconomic services (Tesemma, 2007). These are banana-based multi-story gardens, teff and acacia integrated agroforestry, boundary eucalyptus and cereal crops in agroforestry, conservation based agroforestry, vertically and horizontally packed agroforestry, multi-strata perennial crop agroforestry, enset-coffee-tree-spicebased agroforestry, fruit trees-bamboo combined with enset vegetable farming and bamboo combined with cereal farming. Moreover, Bishaw (2001) indicated that alley cropping with hedgerows of trees or shrubs and annual crops, fodder tree planting mixed with grass and herbaceous legumes on unproductive pasturelands are other important AFPs in Ethiopia.

Homegardens agroforestry systems are the most popular in most parts of Ethiopia (Abebe, 2005; Mengistu \& Hager, 2009; Agize et al., 2013). It is found manly in Southern and southwestern regions of Ethiopia ((Negash et al., 2012; Abebe , 2010 ; Moges, 2009; Muleta et al., 2007) and North-Western Ethiopia (Linger,2014). These are characterized by high species diversity and usually 3-4 vertical canopy strata ( tree layers upper storey, herbaceous layer near the ground and intermediate layers in between. Trees like Cordia Africana, Milletia fruginea, Albezzia gummifera, Ficus spp, and Acacia spp, are among the species that form the upper storey of home gardens.

The practice to maintain trees in croplands is also a common traditional agroforestry practice in Ethiopia. In this agroforestry practice, trees from the original vegetation are retained and are encouraged to regenerate in the arable fields and pastures. The canopy cover reaches 5-15\%, for example in central Rift Valley (Belayhun, 2011). The trees are chosen for their general usefulness providing multiple products such as fodder, fruit, fuel wood, medicinal products or vegetable. The fertility benefits of Moringa stenopetala (Abay et al., 2013; Solbamo, 2011), Faidherbia albida (Degu, 2010); Croton macrostachyus (Ashagre et al., 1998); Cordia africana (Yadesa et al., 2001); Millettia ferruginea (Hailu et al., 2000); Hypericum revolutum (Kewessa et al., 2015) have been demonstrated so far. Among parkland tree species, the potential of $F$. albida is well recognized.

\subsection{Potential role of agroforestry for climate change mitigation and adaptation}

Climate change mitigation is the natural process of removing excess carbon dioxide $\left(\mathrm{CO}_{2}\right)$ from the atmosphere and storing it in long lived pools of carbon by fixing it or locking it up from being released back to atmosphere. The pools here include both aboveground and belowground plant biomass. The belowground biomass 
components of plants include root, soil microorganism and the relatively stable forms of organic and inorganic carbon in soils (Nair et.al, 2009).

Agroforestry systems are often taking up large amounts of $\mathrm{CO}_{2}$ from the atmosphere and storing the $\mathrm{C}$ in standing vegetation (biomass), soil organic matter, and harvested biomass products ( Montagnini and Nair 2004; Schoeneberger 2009).

The Intergovernmental Panel for Climate Change (IPCC 2007) report concluded that agroforestry would offer the highest potential of $\mathrm{C}$ sequestration in developing countries (Verchot et al. 2007). Different agroforestry practices have different potential to store carbon and depending on their species composition and different ecological and environmental variables (Kumar and Nair, 2011; Nair et.al, 2009)

A number of studies indicated that agroforestry in the tropics has higher $\mathrm{C}$ densities than field crops or pasture (Albrecht and Kandji, 2003; Nair et al., 2009; Nair, 2012). Currently, agroforestry is estimated to be practiced on 1000-1023 Mha globally and to sequester from 30 to $322 \mathrm{C} \mathrm{Pg} \mathrm{yr}^{-1}$ (Zomer et al, 2009; Jose and Bardhan, 2012). An additional 12,000 Mg of C per year could be sequestered, increasing to 17,000 Mg C per year by 2040 , simply through improving tree management practices. Literatures on carbon stocks and sequestration potential to its role in climate change mitigation have been very limited in agroforestry systems of Ethiopia. Studies in southeastern Ethiopia the average total biomass carbon stock of indigenous agroforestry systems were $67 \mathrm{Mg} \mathrm{ha}^{-1}$ with trees, Coffee accounted for $11 \%$ and enset $9 \%$ of total biomass $\mathrm{C}$ on average of which trees accounting for 39-93\% of the total biomass carbon stock (Negash and Starr, 2015). The same study on the same area indicated that SOC stocks $(0-60 \mathrm{~cm})$ were $109-253 \mathrm{Mg} \mathrm{ha}^{-1}$ in the indigenous agroforestry systems. Other authors also investigated the aboveground biomass carbon stock of coffee based agroforestry was $18.66 \mathrm{t} \mathrm{C}^{-1}$ (Seta and Demissew, 2014). Other studies in Wolayitta Zone, Ethiopia, Homegarden and parkland agroforestry accounts total carbon stock of $86.4(\mathrm{Mg} / \mathrm{ha}$ and $51 \mathrm{Mg} / \mathrm{ha}$ respectively, (Bajigo et al., 2015). The potential of agroforestry systems to sequester carbon varies depending upon the type of the system, species composition, and age of component species, geographic location, environmental factors, and management practices (Jose, 2009). The carbon sequestered within agroforestry systems may have a positive impact on the global GHG balance (Harvey et al. 2010).

\subsection{Agroforestry and biodiversity conservation}

Agroforestry increases biodiversity through the integration of trees, shrubs, crops and/or animals into the system. Agroforestry contributes to biodiversity conservation through outside and inside their habitat. The inside contribution of Agroforestry to biodiversity conservation is through: (i) the provision of supplementary habitats for species (Jose 2009); (ii) conservation of remnant native species and their gene pools (Das and Das 2005; Harvey and Villalobos, 2007); (iii) preventing the degradation and loss of surrounding habitat; (iv) buffering the pressure on deforestation of the surrounding natural habitat; and v) provision of corridors and stepping stones for persistence and movement of area-sensitive floral and faunal species through linking fragmented habitats in the landscape (Nyhus and Tilson, 2004, McNeely and Schroth,2006, Bhagwat et al. 2008, Jose 2009). Agroforestry systems also help to maintain a high number of species outside their native forest habitat through reducing the pressure of humans on natural forest and keeping valuable tree species on their farms act as islands or refuges (Tolera et al., 2008). For example, study showed that converting coffee and cocoa agroforestry systems to plantation reduced total species richness by $46 \%$ while the conversion of natural forest to agroforestry resulted in only an $11 \%$ reduction in species richness (De Beenhouwer et al., 2013).

Various agroforestry systems practice in different parts of Ethiopia has contributed to biodiversity conservation. One of the oldest indigenous agroforestry systems that were practiced in Hararghe highlands of eastern Ethiopia is the retaining of scattered apple-ring Acacia (Faidherbia albida (Delile) A. Chev.) (Poschen, 1986). Different Studies as indicate in the table 1 agroforestry practices in different parts of Ethiopia contribute the retention of woody species in the farmlands. Some of the woody species retaining in agroforestry system were mainly Cordia africana, Eucalyptus camaldulensis, Millettia ferruginea and Euphorbia candelabrum (Mengesha, 2010), and Albizia gummifera , Acacia abyssinica, Ficus sur and Ficus vasta ( Muleta et al. 2008). 
Table 1. Agroforestry systems at different parts of Ethiopia and their contribution to biodiversity conservation

\begin{tabular}{|c|c|c|c|c|}
\hline $\begin{array}{ll}\text { Type } & \text { of } \\
\text { Agroforestry } \\
\text { system }\end{array}$ & Study place & Vegetation type & $\begin{array}{l}\text { No. woody } \\
\text { species } \\
\text { found }\end{array}$ & Sources/reference \\
\hline \multicolumn{5}{|l|}{ Southeast Ethiopia } \\
\hline $\begin{array}{l}\text { Traditional } \\
\text { agroforestry }\end{array}$ & Sinan district, bale zone & Woody species & 55 & $\begin{array}{l}\text { Molla } \\
\text { Kewessa,2015 }\end{array}$ \\
\hline \multicolumn{5}{|l|}{ North } \\
\hline Fruit trees farms & Adiarkay, Debark, Dejen & $\begin{array}{l}\text { Edible indigenous } \\
\text { fruit trees }\end{array}$ & 17 & $\begin{array}{l}\text { Fentahun \& Hager } \\
(2010)\end{array}$ \\
\hline Homegraden & Hintalo Wejerat of Tigra & $\begin{array}{l}\text { Fruits \& fodder } \\
\text { trees, vegetables, } \\
\text { herbs }\end{array}$ & $40(66)$ & $\begin{array}{l}\text { Haileselasie \& } \\
\text { Gebrehiwot (2012) }\end{array}$ \\
\hline \multicolumn{5}{|l|}{ South } \\
\hline Coffee-enset system & $\begin{array}{l}\text { Four districts, Sidama } \\
\text { zone }\end{array}$ & $\begin{array}{l}\text { Woody species }+ \\
\text { cultivated crops }\end{array}$ & $198(61)$ & Abebe et al. (2006) \\
\hline $\begin{array}{l}\text { Traditional } \\
\text { homegardens }\end{array}$ & $\begin{array}{l}\text { Around Gate Uduma, } \\
\text { Gedeo }\end{array}$ & $\begin{array}{l}\text { Trees, shrubs, } \\
\text { herbs }\end{array}$ & $165(31)$ & Debessa (2011) \\
\hline $\begin{array}{l}\text { Indigenous } \\
\text { agroforestry }\end{array}$ & $\begin{array}{l}\text { Aleta wondo district, } \\
\text { Gedeo }\end{array}$ & $\begin{array}{l}\text { Trees, shrubs, } \\
\text { vegetable crops }\end{array}$ & $50(40)$ & $\begin{array}{l}\text { Negash } \quad \& \quad \text { Achalu } \\
(2008)\end{array}$ \\
\hline $\begin{array}{l}\text { Various } \\
\text { homegardens }\end{array}$ & $\begin{array}{l}\text { Wolayta and Gurage } \\
\text { zoneo }\end{array}$ & $\begin{array}{l}\text { All floristic } \\
\text { species }\end{array}$ & 60 & $\begin{array}{l}\text { Asfaw } \quad \& \quad \text { Woldu } \\
(1997)\end{array}$ \\
\hline \multicolumn{5}{|l|}{ Southwest } \\
\hline Homegardens & Basketo, Kafa zone & $\begin{array}{l}\text { Trees, shrubs, } \\
\text { climbers, spice }\end{array}$ & $\begin{array}{c}149-192 \\
(30-32)\end{array}$ & Woldeyes (2011) \\
\hline \multicolumn{5}{|l|}{ Central } \\
\hline Trees on farms & Three districts, Arsi zone & Woody species & 90 & \multirow{2}{*}{$\begin{array}{l}\text { Mengesha (2010) } \\
\text { Kebede }(2010)\end{array}$} \\
\hline Homegardens & Sebeta-Hawas district & $\begin{array}{l}\text { Trees, shrubs, } \\
\text { herbs, climbers }\end{array}$ & $14(30)$ & \\
\hline Trees on farms & Welmera \& Alemgana & Tree species & 27 & $\begin{array}{l}\text { Duguma } \\
(2010)\end{array} \quad \& \quad$ Hager \\
\hline Homegardens & $\begin{array}{l}\text { Beseku, Arsi Negelle } \\
\text { district }\end{array}$ & Woody species & 64 & Tolera et al. (2008) \\
\hline \multicolumn{5}{|l|}{ Country level } \\
\hline Agroforestry systems & $\begin{array}{l}\text { West, north and south } \\
\text { Ethiopia }\end{array}$ & $\begin{array}{l}\text { Trees }+ \text { shrubs }+ \\
\text { climbers }+ \text { herbs }\end{array}$ & $429(27)$ & Asfaw (2002) \\
\hline Homegardens & $\begin{array}{l}\text { Central, eastern, western, } \\
\text { south Ethiopia }\end{array}$ & $\begin{array}{ll}\text { All } & \text { floristic } \\
\text { species } & \end{array}$ & 162 & $\begin{array}{l}\text { Asfaw } \\
(1995)\end{array}$ \\
\hline
\end{tabular}

The value in the parenthesis shows that percentage of trees; sources Negash et.al 2013

\section{Conclusion and recommendation}

Though type of agroforestry practice not yet well documented in Ethiopia eight AFPs like alley cropping, trees in homegardens, fodder tree planting, trees as living fences, farm boundary and road side planting, trees on contour bunds, and gully planting as age-old AFPs in Ethiopia. Homegardens agroforestry systems are the most popular in most parts of Ethiopia. It is found manly in Southern and southwestern regions of Ethiopia and North-Western Ethiopia.

Different agroforestry practices have different potential to store carbon and depending on their species composition and different ecological and environmental variables. A number of studies indicated that agroforestry in the tropics has higher $\mathrm{C}$ densities than field crops or pasture. Currently, agroforestry is estimated to be practiced on 1000-1023 Mha globally and to sequester from 30 to $322 \mathrm{C} \mathrm{Pg} \mathrm{yr}^{-1}$. Agroforestry practices also increases biodiversity through the integration of trees, shrubs, crops and/or animals into the system. For example, study showed that converting coffee and cocoa agroforestry systems to plantation reduced total species richness by $46 \%$.

Therefore, expanding and practicing of agroforestry practices are one of the means to retaining the species and reducing the emission of GHG into the atmosphere. 


\section{Conflict of interest}

The authors declare that they have no conflict of interest.

\section{References}

Abebe, T., Wiersum, K.F., Bongers, F. \& Sterck, F. 2006. Diversity and dynamics in homegardens of southern Ethiopia. In: B.M. Kumar \& P.K.R. Nair (Eds.). Tropical homegardens: a time-tested example of sustainable agroforestry, p.123-142.

Abebe, T., 2005. Diversity in homegarden agroforestry systems of southern Ethiopia. Wageningen University, Wageningen, Netherlands.

Albrecht A, Kandji ST., 2003. Carbon sequestration in tropical agroforestry systems. Agric Ecosyst Environ 99:15-27. doi: 10.1016/S0167-8809(03)00138-5

Asfaw, Z., 2002. Homegardens in Ethiopia: some observations and generalizations. In: Homegardens and in-situ conservation of plant genetic resources in farming systems. Watson, J.W. \& Eyzagurre, P. B., (Eds.). Proceedings of the 2nd international homegardens workshop, 17-19 July 2001. Witzenhausen, Federal Republic of Germany

Asfaw, Z. \& Woldu, Z., 1997. Crop association of home-gardens in Wolayta and Gurage in southern Ethiopia. Ethiopian Journal of Science 20(1):73-90.

Ashagrie Y, Mamo T, Olsson M., 1998. Changes in Some Soil Chemical Properties under Scattered Croton macrostachyus Trees in the Traditional Agroforestry System in North-Western Ethiopia. Ethiopian J. Natural Resourc. 1(2): 215-233.

Asfaw, Z. \& Nigatu, A., 1995. Home-gardens in Ethiopia: Characteristics and plant diversity. Ethiopian Journal of Science 18(2):235-266.

Agize, M., Demissew, S.\& Asfaw, Z., 2013. Indigenous knowledge on management of home gardens and plants in Loma and Gena Bosa Districts (Weredas)of Dawro Zone, southern Ethiopia: plant biodiversity conservation, sustainable utilization and environmental protection. IJSBAR, 10(1), 63-99.

Bajigo A, Tadesse M, Moges Y, Anjulo A., 2015. Estimation of Carbon Stored in Agroforestry Practices in Gununo Watershed, Wolayitta Zone, Ethiopia. Bajigo et al., J Ecosys Ecograph 2015, 5:1 http://dx.doi.org/10.4172/2157-7625.1000157

Bhagwat, S.A., Willis, K.J., Birks, H.J.B. \& Whittaker, R.J., 2008. Agroforestry: a refuge for tropical biodiversity? Trends in Ecology and Evolution 23(5): 261-265.

Bishaw, B., Neufeldt, H., Mowo, J., Abdelkadir, A., Muriuki, J., Dalle, G., Assefa, T., Guillozet, K., Kassa, H., Dawson, I.K., Luedeling, E. \& Mbow, C., 2013. Farmers' strategies for adapting to and mitigating climate variability and change through agroforestry in Ethiopia and Kenya. In: Davis, C.M., Bernart, B. \& Dmitriev, A. (Eds.). Forestry Communications Group, Oregon State University, Corvallis, Oregon.

Bishaw, B., 2001. Deforestation and land degradation in Ethiopian highlands: a strategy for physical recovery. Northeast African Studies, 8(1), 7-26.

Brown, S., Grais, A., Ambagis, S. \& Pearson, T., 2012. Agricultural GHGs in East and West Africa,baseline emission and mitigation potential CCAFS Working Paper (No. 13). CGIAR Research Program on Climate Change, Agriculture and Food Security (CCAFS). Copenhagen, Denmark. Available at: www.ccafs.cgiar.org. Accessed on 21.11.2014

Carney, S., Green, N. Wood, R. Read R., 2009. Greenhouse Gas Emissions Inventories for Eighteen European Regions, EU CO 80/50 Project Stage 1: Inventory Formation. The Greenhouse Gas Regional Inventory Protocol (GRIP).

Das, T. \& Das, K.A., 2005. Inventorying plant biodiversity in homegardens: A case study in Barak valley, Assam, north-east India. Current Science 89(1):155-163.

De Beenhouwer, M., Aerts, R. \& Honnay, O., 2013. A global meta-analysis of the biodiversity and ecosystem service benefits of coffee and cacao agroforestry: review. Agriculture, Ecosystems and Environment 175:17.

Debessa, S.T., 2011. Study of useful plants Gedeo homegardens Ethiopia in and around Gate Uduma gardens in Kochere Wereda of Gedeo Zone, Ethiopia: an ethnobotanical approach. M.Sc. thesis Addis Ababa University, Ethiopia. P. 144.

Duguma, L.A. \& Hager, H., 2010. Woody plants diversity and possession, and their future prospects in smallscale tree and shrub growing in agricultural landscapes in central highland of Ethiopia. Small-scale Forestry 9:153-174

Ethiopian CRG,, 2011. Ethiopia's Climate-Resilient Green Economy, FEDERAL DEMOCRATIC REPUBLIC OF ETHIOPIA.

Fentahun, M. \& Hager, H., 2010.Integration of indigenous wild woody perennial edible fruit bearing species in the agricultural landscapes of Amhara region, Ethiopia. Agroforestry Systems 78:79-95.

Haileselasie, T.H., Gebrehiwot, M.T., Gebremichael, G.E. \& Hiluf, S.A., 2012. Agroforestry practices and 
biodiversity management in backyards in Hiwane, Hintalo Wejerat of Tigray, Northern Ethiopia. Asian Journal of Agricultural Sciences 4(2): 110-116.

Hailu, H. \& Asfaw, Z., 2011. Homegardens and agrobiodyversity conservation in Sabata town, Oromia Regional State, Ethiopia. Ethiop. J. Sci., 34(1), 1-16.

Hailu T, Negash L, Olsson M., 2002. Millettia ferruginea from Southern Ethiopia: Impacts on soil fertility and growth of maize. Agroforest. Syst., 48: 9-24.

Harvey, C.A. \& Villalobos, G.J.A., 2007. Agroforestry systems conserve species-rich but modified assemblage of tropical birds and bats. Biodiversity and Conservation 16:2257- 2292.

Harvey, C.A., Zerbock O., Papageorgiou S., and Parra A., 2010. What is needed to make REDD+ work on the ground? Lessons learned from pilot forest carbon initiatives. Conservation International, Arlington, Virginia, USA. www.conservation.org/Documents/CI_REDD_Lessons_Learned. PDF

Hoekstra, D. A., Torquebiau, E. \& Bishaw, B., 1990. Agroforestry: potentials and research needs for the Ethiopian highlands (p. 115). Nairobi, Kenya: Agroforestry Research Network, ICRAF.

Hansen MC, Potapov PV, Moore R, Hancher M, Turubanova SA, Tyukavina A., 2013. High resolution global maps of 21st-century forest cover change. Science. 2013; 342(6160):850-3. doi: 10.1126/ science.1244693 PMID: 24233722.

IPCC, 2007. Climate Change 2007: Mitigation of Climate Change. Working Group III contribution to the Intergovernmental Panel on Climate Change, Fourth Assessment Report. Cambridge, UK.

ICRAF., 2000. Paths to prosperity through agroforestry. ICRAF's corporate strategy, 2001-2010. Nairobi: International Centre for Research in Agroforestry.

Jose, S. \& Bardhan, S., 2012. Agroforestry for biomass production and an overview. Agroforestry Systems $86: 105111$.

Jose,S., 2009. Agroforestry for ecosystem services and environmental benefits: an overview. School of Forest Resources and Conservation, University of Florida Agroforest Syst (2009) 76:1-10

Kebede, T.M., 2010. Homegardens agrobiodiversity conservation in Sebeta-Hawas Wereda, southwestern Shewa Zone of Oromia Region, Ethiopia. M.Sc. thesis. Addis Ababa University, Ethiopia. p.78.

Kewessa, G., Lemma, T., Abiot, M.,. 2015. Effects of Hypericum revolutum (Vahl) tree on major soil nutrients and selected soil Physico-chemical properties in Goba District, Oromia, Ethiopia. Wudpecker. J. Agric. Res., 4(1): $006-013$.

Kumar BM, Nair PKR., 2011. Carbon Sequestration Potential of Agroforestry Systems: Opportunities and Challenges. Springer Science+Business Media 8: 326.

Linger, E., 2014. Agro-ecosystem and socio-economic role of homegardens agroforestry in Jabithenan District, North-Western Ethiopia: implication for climate change adaptation. SpringerPlus 2014 3:154. doi:10.1186/2193-1801-3-154

Mairie de Paris, 2009. Le Bilan Carbone de Paris: Bilan des émissions de gaz à effet de Serre

McNeely, J.A. \& Schroth, G. 2006. Agroforestry and biodiversity conservation- traditional practices, present dynamics, and lessons for the future. Biodiversity and Conservation 15:549-554.

Mengesha, B., 2010. Alternative technologies for sustainable agricultural production and agroecosystem conservation in Arsi highlands, south-eastern Ethiopia. PhD thesis. Addis Ababa University, Ethiopia. p. 198.

Mengistu, F. \& Hager, H., 2009. Integration of indigenous wild woody perennial edible fruit bearing species in the agricultural landscapes of Amhara region, Ethiopia. Agroforestry Systems, 78(1), 79-95. doi:10.1007/s10457-009-9239-5

Molla , A . \& Kewessa, G., 2015. Woody Species Diversity in Traditional Agroforestry Practices of Dellomenna District, Southeastern Ethiopia: Implication for Maintaining Native Woody Species. Hindawi Publishing Corporation International Journal of Biodiversity Volume 2015, Article ID 643031, 13 pages http://dx.doi.org/10.1155/2015/643031

Montagnini F, Nair PKR., 2004. Carbon sequestration: An underexploited environmental benefit of agroforestry systems. Agroforest Syst 61:281-295

Muleta, D., Assefa, F., Nemomissa, S. \& Granhall, U., 2007. Composition of coffee shad tree species and density of indigenous arbuscular mycorrhizal fungi (AMF) spores in Bonga natural coffee forest, southwestern Ethiopia. Forest Ecology and Management 241:145- 154.

Muleta, D., Assefa, F. \& Nemomissa, S., 2008. Distribution of arbuscular mycorrhizal fungi spores in soils of smallholder agroforestry and monocultural coffee systems in southeastern Ethiopia. Biology and Fertility of Soils 44:653-659.

Nair. K. R, Kumar.B. M and Nair.V. D., 2009. Agroforestry as a strategy for carbon sequestration; J. Plant Nutr. Soil Sci, 172: 10-23.

Nair PKR., 2012. Carbon sequestration studies in agroforestry systems: a reality-check. Agroforest Syst 86:243253. doi: 10.1007/s10457-011-9434-Z 
Negash, M. \& Achalu, N., 2008. History of indigenous agroforestry in Gedeo, southern Ethiopia, Based on local community interviews: vegetation diversity and structure in the land use systems. Ethiopian Journal of Natural Resources 10(1):31-52.

Negash,N., Yirdaw,E. Luukkanen, O., 2012. Potential of indigenous multistrata agroforests for maintaining native floristic diversity in the south-eastern Rift Valley escarpment, Ethiopia. Agroforestry Systems 85:928. DOI 10.1007/s10457-011-9408-1.

Negash M, Starr M., 2015. Biomass and soil carbon stocks of indigenous agroforestry systems on the southeastern Rift Valley escarpment, Ethiopia. An International Journal on Plant-Soil Relationships. DOI $10.1007 / \mathrm{s} 11104-015-2469-6$

Nyhus, P. \& Tilson, R., 2004. Agroforestry, elephants, and tigers: balancing conservation theory and practice in human-dominated landscapes of South-east Asia. Agriculture, Ecosystems and Environment 104:87-97.

Poschen, P., 1986. An evaluation of the Acacia albida-based agroforestry practices in the Hararghe highlands of eastern Ethiopia. Agroforestry Systems 4:129-143.

Seta T and Demissew S., 2014. Diversity and standing carbon stocks of native agroforestry trees in wenago district, Ethiopia. journal of Emerging Trends in Engineering and Applied Sciences (JETEAS) 5(7): 125132.

Schoeneberger MM., 2009. Agroforestry: working trees for sequestering carbon on agricultural lands. Agroforest Syst 75: 27-37. doi:10.1007/s10457-008-9123-8

SLUF., 2006. Indigenous agroforestry practices and their implications on sustainable land use and natural resources management: the case of Wonago Woreda (p. 101). Addis Ababa, Ethiopia.

Tesemma, A. B., 2007. Profitable agroforestry innovations for eastern Africa: experience from 10 agroclimatic zones of Ethiopia, India, Kenya, Tanzania and Udganda (p. 388). Nairobi, Kenya. World Agroforestry Center.

Tolera, M., Asfaw, Z., Lemenih, M. \& Karltun, E., 2008. Woody species diversity in a changing landscape in the south-central highland of Ethiopia. Agricultural, Ecosystems and Environment 128:52-58.

VanKooten, G.C., 2000. Economic dynamics of tree planting for carbon uptake on marginal

agricultural lands. Canadian Journal of Agricultural Economics 48:51-65.

Verchot LV,Noordwijk MV,Kandji S,Tomich T,Ong C,Albrecht A, Mackensen J, Bantilan C, Anupama KV, Palm C., 2007. Climate change: linking adaptation and mitigation through agroforestry. Mitig Adapt Strat Glob Change 12:901-918. doi:10.1007/s11027-007-9105-6

Woldeyes, F., 2011. Homegardens and spices of Basketo and Kafa (Southwest Ethiopia): Plant diversity, product valorization and implications to biodiversity conservation. $\mathrm{PhD}$ thesis. Addis Ababa University, Ethiopia.

Yadessa A, Itanna F, Olsson M. , 2001. Contribution of Indigenous Trees to Soil Properties: The Case of Scattered Trees of Cordia africana Lam. in Croplands of Western Oromia. Ethiopian J. Natural Resourc. 3(2): 245-270.

Zomer RJ, Trabucco A, Coe R, Place F. 2009. Trees on farm: analysis of global extent and geographical patterns of agroforestry. ICRAF Working Paper No. 89. Nairobi, Kenya: World Agroforestry Centre 